\title{
Sytuacja liryczna a konstruktywistyczny podział na Naturę i Kulturę: Julian Przyboś, „Z Tatr”
}

Krzysztof Obremski 


\title{
Sytuacja liryczna a konstruktywistyczny podział na Naturę i Kulturę: Julian Przyboś, Z Tatr
}

\author{
Krzysztof Obremski
}

TEKSTY DRUGIE 2017, NR 4, S. 235-252

DOI: $10.18318 /$ td.2017.4.15

Gdyby można było rzucić się nie w dół, ale w górę, w otchłań nieba. W niebospaść!

Julian Przyboś1

W 1926 roku czytelnicy „Zwrotnicy” mogli przeczytać tekst opatrzony znamiennym tytułem Człowiek nad przyrodą. Tamże Julian Przyboś prowokacyjnie zwerbalizował ówczesny awangardowy kult maszyny i związaną z nim futurologię ${ }^{2}$ np. należy pogodzić się z myślą, że w przyszłości (tj. za kilka czy kilkanaście lat) jedyną

1 Pochodzące z 1968 roku słowa cyt. za: J. Kwiatkowski Świat poetycki Juliana Przybosia, PIW, Warszawa 1972, s. 84.

2 W maju 1969 roku Przyboś wyjaśniał, „W dwóch moich pierwszych zbiorkach [Śruby - 1925; Oburq̨cz - 1926], zawierających jakby ody i hymny na cześć człowieka pracy, uskrzydlonego przez nowoczesne moce produkcyjne, gotującego się do lotów kosmicznych, wiązałem budowanie i wznoszenie wierszy bezpośrednio z trudem rąk i pędem maszyn". J. Przyboś Od autora, w: J. Przyboś Utwory poetyckie. Zbiór, Ludowa Spółdzielnia Wydawnicza, Warszawa 1971, s. 8.
Krzysztof Obremski

- prof. dr hab., kierownik Zakładu Literatury Staropolskiej (Instytut Literatury Polskiej UMK). W ostatnich latach wydał książki: Literatura staropolska czytana współczesnq humanistykq (2012), Wizerunki medialne polityków: Lech Kaczyński-Donald Tusk - Bronisław Komorowski (2014), Ciało - płeć - kultura (2015). Kontakt: obremski@ umk.pl 
wspinaczką na Mnicha będzie wjazd windą elektryczną. W tymże tekście, ówcześnie wywołującym gwałtowne głosy sprzeciwu, tatrzańskie szczyty zostały przedstawione również wręcz antypoetycko, tzn. także jako wyzwanie biznesowe:

Góra jest teraz piękna dlatego, że mogę ją zdobyć, jeśli jestem turystą; że mogę ją przebić tunelem, jeśli jestem inżynierem; że mogę na niej zarobić, jeśli jestem właścicielem schroniska; jest piękna dlatego, że mam świadomość tej jej roli twórczej w stosunku do turysty, inżyniera, hotelarza... i że na świadomości tej mogę oprzeć budowę poematu, jeśli jestem poeta. ${ }^{3}$

W 1926 roku Przyboś pozostawał nieświadomy tego, jak okrutnie i może nawet niedorzecznie trzy lata później zabrzmią jego słowa - kiedy szóstego października 1929 roku na południowej ścianie Zamarłej Turni jeszcze kilkunastoletnie siostry Marzena i Lida Skotnicówny podejmą swą ostatnią wspinaczkę. Ta pierwsza była przez niego kochana. Po czterech latach od owej tragedii, pierwszego lipca 1933 roku (ta data widnieje w autografie ${ }^{4}$ ) powstanie wiersz Z Tatr.

Pamięci taterniczki, która zginęła na Zamartej Turni

\section{Z TATR}

Słyszę:

Kamieniuje tę przestrzeń niewybuchły huk skał.

To - wrzask wody obdzieranej siklawą z łożyska i gromobicie ciszy.

Ten świat, wzburzony przestraszonym spojrzeniem, uciszę, lecz -

Nie pomieszczę twojej śmierci w granitowej trumnie Tatr.

3 Cyt. za: J.A. Szczepański Góry w twórczości Juliana Przybosia. "Wierchy” 1963 (XXXII), s. 136-137.

4 J. Przyboś Utwory poetyckie, opr. R. Skręt, przedmowa J. Kwiatkowski, Wydawnictwo Literackie, Kraków 1984, s. 509. 
To zgrzyt

czekana,

okrzesany z echa,

to tylko cały twój świat

skurczony w mojej garści na obrywie głazu;

to - gwałtownym uderzeniem serca powalony szczyt.

Na rozpacz - jakże go mało!

A groza - wygórowana!

Jak lekko

turnię zawisłą na rękach

utrzymać

i nie paść,

gdy

w oczach przewraca się obnażona ziemia

do góry dnem krajobrazu,

niebo strącając w przepaść!

Jak cicho

W zatrzaśniętej pięści pochować Zamarłą․

W przypisie przeczytamy wyjaśnienie: „[...] Motto odnosi się do Marzeny Skotnicówny, uczennicy i narzeczonej Przybosia, alpinistki, która wraz ze swoją siostrą Lidą zginęła tragicznie 6 X 1929 r. na południowej ścianie Zamarłej Turni w Tatrach. [...]"6. Mniejsza o to, że słowo „narzeczona” to następstwo biograficznej nadinterpretacji (o czym dalej). Ważniejsze co innego, mianowicie owa tatrzańska tragedia może stać się początkiem uogólniającego spojrzenia: od sytuacji lirycznej ${ }^{7}$ i świata wierszem przedstawione-

5 J. Przyboś Sytuacje liryczne. Wybór poezji, wstęp E. Balcerzan, wybór E. Balcerzan, A. Legeżyńska, komentarze A. Legeżyńska, Ossolineum, Wrocław 1989, s. 95-96.

6 Tamże, s. 95 .

7 „W centrum teorii liryki Przybosia znajduje się kategoria "sytuacji lirycznej”. Kategoria ta obejmuje jednocześnie - mówiąc tradycyjnie - życie i twórczość autora. Odnosi się zarówno do procesu pisarskiego, jak i do dzieła. "Sytuacje liryczne” zdarzają się każdemu z nas, są momentami naszej biografii; poeta je utrwala, oddaje we władanie sztuce słowa, czyni z nich dominantę kompozycyjną wiersza („poematu”, jak mówili Peiper i Przyboś, mając na myśli nie gatunek, lecz dowolnej długości utwór poetycki). Sytuacja autora powtarza się jako sytuacja podmiotu, bohatera tekstu. Powtarza się w świecie szczególnym, bytującym w języku i manifestującym 
go ${ }^{8}$ do problematyki konstruktywistycznego podziału na Naturę i Kulturę. Wiersz Z Tatr to pokaz tryumfu poetyckiej wyobraźni Przybosia nad brakiem osobistego doświadczania taternickich dróg wspinaczkowych (stan zdrowa pozwalał mu co najwyżej na wędrowanie po Tatrach szlakami turystyczny$\mathrm{mi})^{9}$. Porównanie wiersza $Z$ Tatr z tymi powstałymi po śmierci np. Wandy Rutkiewicz bądź Tadeusza Piotrowskiego (wierszami niejako „dosłownymi” $\mathrm{w}$ przedstawianiu tragicznych wydarzeń oraz emocji nimi ewokowanych) pozwoliłoby pełniej dostrzec, czym było Przybosiowe ekwiwalentyzowanie uczuć.

Już w słowach dedykacji - „Pamięci taterniczki, która zginęła na Zamarłej Turni" - została zawarta, jednak tylko wstępnie czy raczej potencjalnie, problematyka relacji między Naturą a Kulturą. Te znamiennie bowiem różnią się pamięciami. Natura, której niepodobna przypisywać jakiekolwiek inne formy pamięci niż przyrodnicza, poprzestaje na mniej lub bardziej wyraźnych śladach działań jej sił: doliny wydrążone wodami płynących nimi rzek czy strumieni, łąki wypalone słońcem, lasy powalone uderzeniami wichury, muł pokrywający tereny zalane powodzią, brzeg morza niejako rzeźbiony falami, skały z ich erozją pod wpływem czynników atmosferycznych... Inna

się wyłącznie przez język - a więc powtarza się i nie powtarza, "nie-i-jest” rekonstrukcją realności przedsłownej". E. Balcerzan Wstęp, do: J. Przyboś Sytuacje liryczne, s. LXVII.

8 Por. K. Obremski Zamarła Turnia, siostry Skotnicówny i ekwiwalentyzowanie: „Z Tatr"|uliana Przybosia, "Pamiętnik Literacki” 2011, z. 2, s. 129-142. Rzeczownik odczasownikowy "ekwiwalentyzowanie" adekwatniej niż "ekwiwalencja” oddaje procesualność powstawania wiersza. "Ekwiwalentyzowanie, rozumiane jako operacja na rzeczach wprowadzonych do poetyckiego obrazu, samo miało być z kolei ekwiwalentem określonych treści uczuciowych podmiotu". J. Sławiński Koncepcja języka poetyckiego awangardy krakowskiej, Ossolineum, Wrocław 1965, s. 153.

9 Moje osobiste doświadczenia pozwalają mi przyznać sobie przynajmniej elementarną kompetencję taternicką. Bez niej trudno o uniknięcie potknięć takich jak np. te słowa: „od chwili obsunięcia się czekana, kiedy utrzymanie ręką głazu zadecydować ma o życiu [...] to nie człowiek odpada od szczytu, to szczyt jest powalony [...]". A. Okopień-Sławińska Julian Przyboś „Z Tatr”, w: Czytamy utwory współczesne. Analizy, red. T. Kostkiewiczowa, A. Okopień-Sławińska, J. Sławiński, PZWS, Warszawa 1967, s. 128. Otóż: 1. Skotnicówny wspinały się jeszcze w sezonie letnim (zanim zimowy śnieg zasypywał Tatry), więc "czekan" (konieczny, aby np. wyrąbywać stopnie w zlodzonym śniegu) pozostanie jedynie poetyzmem 2. Lida nie utrzymywała ręką głazu (to wymagałoby siły nadludzkiej), lecz trzymała się go ręką. 3. Skotnicówny nie doszły do grani Zamarłej Turni - od ściany odpadły gdzieś w połowie drogi wspinaczkowej, więc o jakimkolwiek odpadaniu od szczytu nie może być mowy. Także w komentarzu Anny Legeżyńskiej (Julian Przyboś, Sytuacje liryczne, s. 95) do wiersza Z Tatr znalazły się dwa błędy rzeczowe: Lida Skotnicówna nie była "alpinistką" - lecz taterniczką; „siklawa” to nie strumień tatrzański, ale wodospad - o długości dochodzącej do kilkudziesięciu metrów. 
jest pamięć Kultury - ta cząstkowa, związana z tragiczną śmiercią Marzeny, do czasu pozostanie zachowana jako jedna z tatrzańskich opowieści o ofiarach gór. Obie pamięci, Natury i Kultury, w czasie trwają nieporównywalnie. Deszcze co prawda szybko ożywią wypalone słońcem łąki i pamięć o suszy przeminie, jednak wyrzeźbione rzekami wąwozy, przełomy i kaniony pozostają czymś jakby poza zasięgiem granic wyobraźni ludzkich pokoleń. Jakże inaczej rzecz się ma z wierszem Przybosia: takie czy inne nośniki pamięci mogą zapewnić obydwu taterniczkom (teoretycznie może nawet bezkresne) przetrwanie w czasie, jednak kulturowa żywotność ostatniej wspinaczki sióstr będzie zanikać. Nie dlatego bynajmniej, że taternicy znikną z przepastnych ścian, lecz z innego powodu: nawet niegdyś awangardowa, dziś już tradycyjna literatura (nią wszakże staje się poezja awangardy krakowskiej i samego Przybosia) przemienia się w medium ustępujące miejsca innym formom przekazu. Same Tatry, mniej bądź bardziej oczytani w literaturze polskiej taternicy czy tym bardziej turyści - wiersza Z Tatr po prostu nie potrzebują (tym bardziej, że południowej ścianie Zamarłej Turni stosunkowo daleko do ceprowskiego "deptaka” wiodącego od Opalenicy do Morskiego Oka). Z pewnością w niepamięci potomnych wiersz Z Tatr z czasem niemal doszczętnie zaginie - wyłączywszy nielicznych literaturoznawców (o ile jeszcze tacy będą $\left.{ }^{10}\right)$.

Dedykacja „Pamięci taterniczki, która zginęła na Zamarłej Turni” stanowi jakby ramę liryczną wiersza ${ }^{11}$. Niepodobna mówić o jego adekwatności wobec faktograficznego stanu rzeczy, świat przedstawiony słowami Przybosia jest bowiem poetycką konstrukcją. Zamiast wierności relacji naocznych świadków wypadku mamy zapis jakby zapętlonych czy raczej współistotnych

10 „Jednym z najistotniejszych symptomów nadchodzącej śmierci literatury jest stadna ucieczka młodszych badaczy z wydziałów literaturoznawstwa na całym świecie. Od studiów nad literaturą do teorii, studiów kulturowych i postkolonialnych, medioznawstwa (film, telewizja etc.), studiów nad kulturą popularną, studiów kobiecych, studiów afrykańsko-amerykańskich etc. [...] Ich pisarstwo i nauczanie często marginalizuje lub ignoruje literaturę. [...] Ci młodzi ludzie nie są głupi, nie są też ignoranckimi barbarzyńcami. Nie chcą zniszczyć literatury ani literaturoznawstwa. Jednak o wiele lepiej od starszych wiedzą, w którą stronę wieje wiatr". J.H. Miller O literaturze, przeł. K. Hoffmann, Wydawnictwo Naukowe UAM, Poznań 2014, s. 20-21.

11 „Poprzedzająca utwór dedykacja nie tylko informuje, komu został on poświęcony, ale także ma znaczenie komentarza wyjaśniającego genezę tego liryku i ułatwiającego rekonstrukcję przedstawionej w nim sytuacji. [...] Dedykacja wskazuje również, kim jest nieokreślona bliżej w tekście druga osoba i ujawnia, że dystans pomiędzy podmiotem mówiącym a bohaterką i adresatką zarazem - wytyczyła śmierć”. A. Okopień-Sławińska Julian Przyboś, "Z Tatr”, s. 125 . 
emocji dwóch postaci: taterniczki wykreowanej słowami wiersza i samego Przybosia. Mniejsza nawet o to, że jedynie on (od 1927 roku nauczyciel cieszyńskiego gimnazjum, starszy o dziesięć lat od Marzeny) darzył ją najgłębszym uczuciem. Ważniejsza od obyczajowej materii niech będzie literaturoznawcza: wiersz co prawda został zadedykowany Marzenie, jednak wyłącznie jej siostrze Lidzie mogła być dana ta przedśmiertna chwila, którą wiersz nie tyle przekazał, ile wykreował.

Dlaczego dedykacja „Pamięci taterniczki, która zginęła na Zamarłej Turni”, już wstępnie pozwala dostrzec, jak świat przedstawiony wiersza jest poetycką konstrukcją - jakby oderwaną od faktograficznego stanu rzeczy tragicznego wydarzenia? Odpowiedź należy poprzedzić dwoma wyjaśnieniami:

- w jednym z dwóch autografów wiersza (nie w brulionie, lecz już w czystopisie) dedykacja była imienna: „Pamięci Marii Skotnicówny - Julian Przybos”" (jak pisze Krystyna Heska-Kwaśniewicz: „W rękopisie nie ma żadnego szyfru, imię i nazwisko figuruje w oficjalnej wersji") ${ }^{\mathbf{1 2}}$;

- późniejsza dedykacja poprzedzająca wiersz - „Pamięci taterniczki, która zginęła na Zamarłej Turni" - pojawi się w druku dopiero w Miejscu na ziemi z 1945 roku;

- ,jest to w ogóle najdłuższa dedykacja u Przybosia, najchętniej operuje on inicjałami"13.

Tak więc dopiero po kilkunastu latach od tragicznej wspinaczki swe niegdyś najgłębsze emocje osobiste Przyboś pośrednio (wierny teorii ekwiwalentyzowania uczuć) wyraził ${ }^{14}$.

Należy podkreślić: dedykacja „Pamięci taterniczki, która zginęła na Zamarłej Turni" już wstępnie pozwala dostrzec, jak świat przedstawiony wiersza jest poetycką konstrukcją, jakby oderwaną od faktograficznego stanu rzeczy, ponieważ chociaż to kochanej Marzenie wiersz został zadedykowany, jednak postacią wykreowaną słowami Przybosia była Lida. Dowiedzenie zamiany nie tylko samych miejsc sióstr na przepastnej ścianie (wszakże to Lida

K. Heska-Kwaśniewicz Wokół genezy i tekstu "Z Tatr" Juliana Przybosia, "Profile” 1978 nr 10, s. 29 (tekst mieści się na tej jednej stronie czasopisma, więc w kolejnych przypisach paginacja zostanie pominięta).

„W «Kamenie» jednak, ani W « Równaniu serca» żadnego przypisania nie ma, pojawiło się dopiero w «Miejscu na ziemi». Odtąd będzie ono stanowić z wierszem nierozerwalną całość. Zniknęła jednak z dedykacji «Maria Skotnicówna» - pojawiła się «taterniczka», która zginęła na Zamarłej Turni. Było to dość czytelne dla wtajemniczonych, a zupełnie zaszyfrowane dla zwykłego czytelnika i zarazem jakże charakterystyczne dla Przybosiowej dyskrecji". Tamże. 
prowadziła ostatni wyciąg ${ }^{15}$, zaś Marzena pozostawała na stanowisku asekuracyjnym), lecz również tym samym ich poetyckich statusów jest uwarunkowane tym, co wiadomo o samym wypadku:

Jeśli kiedykolwiek, poznawszy już uroki Zawratu, zapragniesz [...] powrócić z [Doliny] Pięciu Stawów na Halę Gąsienicową odmienną drogą - ścieżką przez Kozią Przełęcz - wtedy przystaniesz na chwilę wśród złomisk Pustej Dolinki i ujrzysz widok, który nieprędko uleci z Twej pamięci. Na prawo zwieszać się będą nad Tobą ściany Koziego [Wierchu], na lewo krzesanice Zmarzłych Czub, zaś wprost...

Wprost od północy zagrodzą Ci drogę płyty urwiska, pionowo opadające na piargi doliny. Bije od nich niedostępność, surowa potęga i groza. Bije zuchwała pewność swej mocy. Któż by się poważył atakować ten nieprzebyty mur? Jakiż śmiałek powierzyłby swe życie tym odstraszającym gładkim zerwom? Południowa ściana Zamarłej Turni pozostanie chyba na zawsze symbolem tego, co dla człowieka jest nieosiagalne... [...] 6 października 1929 roku pod ścianą Zamarłej [Turni] zjawiły się dwie młodziutkie urocze dziewczyny. Szesnastoletnia Lida Skotnicówna i jej osiemnastoletnia siostra Marzena postanawiają podjąć próbę pierwszego czysto kobiecego przejścia drogi. Obie należały do najwybitniejszych taterniczek tamtych czasów. Obie miały za sobą trudne przejścia górskie [...]. Czuły się dostatecznie przygotowane i dojrzałe do podjęcia tak poważnego zadania, jakim była Zamarła. [...]

Trudno ustalić z całą pewnością, co było przyczyną odpadnięcia [prowadzącej wspinaczkę] Lidy. Może ukruszenie chwytu, a może - co najprawdopodobniejsze - zmęczenie, wyczerpanie fizyczne, skurcz mięśni. Wątłe siły szesnastoletniej dziewczyny były nadszarpnięte długim podejściem pod ścianę - aż z Zakopanego - a także szybkim tempem wspinaczki. Dlaczego jednak zawiodła asekuracja? Przecież lina wiążąca siostry nie wykazała żadnych uszkodzeń?

W następnym roku znaleziono wiszący na owym haku koło [skalnego] graniastosłupa, rdzą pokryty, rozgięty karabinek. Potężne szarpnięcie liny przy upadku rozgięło stalowy pierścien. Być może, gdyby Lida zapięła na hak nie ten, lecz jakikolwiek inny z posiadanych karabinków byłaby uratowana.

15 Odcinek wspinaczki, jego długość jest określona odległością między stanowiskami asekuracyjnymi. 
Ukryty błąd w fabrykacji sprzętu asekuracyjnego przypieczętował śmierć obu sióstr" ${ }^{16}$.

Już ich wieczną tajemnicą pozostanie to, która wpięła ów karabinek w hak na ostatnim stanowisku asekuracyjnym. Jednak czy na pewno tajemnicę tragedii należy wiązać $\mathrm{z}$ „ukrytym błędem w fabrykacji sprzętu asekuracyjnego"? Może to jedna z sióstr popełniła błąd związany z techniką wspinania się?

Pragnący zachować anonimowość kolega z Klubu Wysokogórskiego w Toruniu opowiedział mi (dnia 17 stycznia 2011 roku), że kiedy przed laty wspinał się na Zamarłą Turnię, wówczas wykorzystywał jako punkt asekuracyjny hak, w który przez dziesięciolecia pozostawał nieszczęsny ów rozgięty karabinek sióstr. Jak wynika z jego słów: jedna z nich popełniła poważny błąd techniczny, gdyż karabinek wpięła w hak w taki sposób, że jeden z jego dwóch dłuższych odcinków (ten bez zamka) nie wisiał swobodnie, lecz pośrodku opierał się na krawędzi skały. Toteż pod wpływem działającej na niego siły szarpnięcia spadającą taterniczką - rozgiął się, ponieważ jeden jego koniec pozostał unieruchomiony przez hak tkwiący w ścianie, a na drugi zadziałała siła spadającej Lidy. W tym rozgięciu się karabinka nie było nic dziwnego: jest on projektowany i wykonywany głównie z myślą o siłach działających wzdłuż, nie zaś w poprzek - a tak właśnie taternicka rzecz miała się 6 października 1929 roku na Zamarłej Turni. Odpowiedź na pytanie o to, która z sióstr popełniła błąd, nieprawidłowo wpiąwszy karabinek w hak, pozostanie ich dosłownie grobową tajemnicą.

Trudno, a nawet niepodobna zakwestionować tego, że w poetyckiej konstrukcji tatrzańskiej tragedii siostry jakby zamieniły się miejscami: odpadnięcie od ściany oraz splecione z tym emocje Lidy Przyboś „przeniósł" na Marzenę. O tym rozstrzyga relacja naocznych świadków wypadku. Paradoksalnie można powiedzieć: Przyboś jedną siostrę kochał (Marzenę), drugą (Lidę) wykreował i tym samym ją zachował w czytelniczej pamięci. Poniekąd tym samym literaturoznawcza wiedza o jego miłości jakby wyparła taternicką wiedzę o tym, która Skotnicówna sza Księgarnia, Warszawa 1985, s. 133-145. Karabinek - podłużny metalowy pierścień, kształtem przypominający wielką agrafkę; odcinek jednego z boków jest otwierany (tamże tzw. zamek). Podczas wspinaczki karabinek łączy wbity w skalną ścianę hak (jest w niego wpięty) i linę (przez jego otwór przeciągniętą). Z czasem wspinacze zaczęli używać karabinków wykonanych zaluminium lub z tytanu (tzn. mocniejszych niż stalowe) i zakręcanych (tym samym "nieotwieralnych" pod wpływem np. szarpnięcia liną) i jakby „nierozginalnych”). 
faktycznie poprowadziła siostrzany zespół na ostatnim wyciągu tragicznej wspinaczki.

Wśród fundamentalnych twierdzeń teorii języka poetyckiego awangardy krakowskiej znajdowało się „ekwiwalentyzowanie uczuć” - w jego kontekście nic więc dziwnego nie będzie w tym, że Przyboś faktografię odpadnięcia sióstr od ściany przewyższył konstrukcją obrazu poetyckiego. Ta siostrzana zamiana miejsc oraz emocji z nimi sprzężonych była podyktowana tym, że Marzena, akurat pozostająca na stanowisku asekuracyjnym i zapewne gwałtownie ściągająca linę ze spadającą w przepaść siostrą (aby skrócić długość lotu i tym samym zmniejszyć siłę szarpnięcia ciężarem spadającego w przepaść ciała), była postacią mniej poetycką. To prowadząca ostatni wyciąg Lida trzymała swe życie w dłoni zaciśniętej na "obrywie głazu" - Marzena mogła tylko wypuszczać kolejne metry liny, co najwyżej spoglądając w górę, aby z większym wyczuciem asekurować siostrę. Kiedy Lida odpadła od ściany, lina wiążąca siostry rozgięła nieprawidłowo wpięty karabinek i wyrwała Marzenę ze stanowiska asekuracyjnego. Dla czytelników wiersza Z Tatr, teorią oraz praktyką ekwiwalentyzowania uczuć jednak jakby oddzielonych od osobistych emocji Przybosia, jedynie asekurująca siostrę Marzena zapewne byłaby postacią słabiej poruszającą emocje niż Lida prowadząca wspinaczkę.

Powtórzę: w taternickiej realności (przynajmniej roboczo przyjmijmy, że taka istnieje) to Lida wspinała się, Marzena zaś pozostawała na stanowisku asekuracyjnym i wypuszczała kolejne metry liny. Dlatego Przybosiowa zamiana miejsc sióstr, a tym samym z nimi splecionych emocji, była poetycką koniecznością - jako postać wykreowana słowami wiersza Marzena, gorączkowo ściągająca linę z już oderwaną od ściany i spadającą Lidą, nie mogłaby z nią równać się. Dopiero piargi Pustej Dolinki, na których obie zakończyły życie, zrównały ich statusy. Owe piargi stały się kresem taternickiego patosu, a zarazem raczej już nie tworzyły poetyckiej scenerii" ${ }^{17}$.

W wierszu Z Tatr Przyboś nie opisuje bynajmniej Tatr Wysokich, tworzy bowiem ich specyficzny obraz - poetycki, zdeterminowany zarówno tragedią sióstr, jak też własnymi emocjami. Światem przedstawionym w wierszu

17 „Wymarły, opustoszały kocioł skalny, zasłany rumowiskiem głazów. Zewsząd otaczają go strome ściany. Dolinka Pusta nie na darmo nosi swą nazwę. Ani śladu w niej bujnej roślinności, kosówek, kwietnych łąk, ani śladu stawu, który by niebieską lub szmaragdową barwą wód łagodził dzikość tego zakątka. Nic, tylko szarość stwardniałych płatów śnieżnych, czerń skał i piargi - beznadziejne pola piargów, to ruchliwych, usypistych, świeżo spadłych ze ścian i żlebów, to znów - na dnie doliny - ogromnych, nieruchomych, pokrytych szorstkim porostem, granitowych bloków". Tamże, s. 133. 
rządzą prawa przeczące fizyce bądź przynajmniej niezależne od niej: głośna niczym gromy cisza uśmierca wysokogórską przestrzeń; siklawa obdziera wodę z łożyska; śmiertelnie przestraszone spojrzenie taterniczki wzburza nieporuszony krajobraz; wypełniające horyzont łańcuchy tatrzańskich szczytów wytyczają przestrzeń zbyt małą, aby pochować ofiarę wspinaczki; w sezonie letnim taternicko niedorzeczny czekan staje się dorzeczny jako symbol wspinaczki; poniekąd monotonne dźwięki dwojakich uderzeń taternickich młotków w haki (wpierw wbijanych w ścianę przez prowadzącą wyciąg taterniczkę, a następnie wybijanych przez drugą) stały się niemym zgrzytem czekana. Przybosiowe Tatry charakteryzuje akustyka przecząca tej realnej pozbawienie echa tego, co dla niego dosłownie naturalne i konstytutywne, tj. powtarzania dźwięków, jawi się jako warunek konieczny, aby ściana Zamarłej Turni oraz piargi Pustej Dolinki zostały wypełnione istotnie grobową ciszą.

Przyboś nie wykreował świata po prostu odwróconego na wspak. Na (można powiedzieć) prostym odwróceniu kierunków działania sił i praw przyrody bowiem nie poprzestał: mikrokosmos Zamarłej Turni stał się makrokosmosem konstytuowanym przedśmiertnymi przeżyciami ofiary wspinaczki oraz poetycką sztuką słowa żałobnika. Świat przedstawiony słowami wiersza Z Tatr to poetycka konstrukcja, w której przerażenie taterniczki śmiercią już stojącą twarzą w twarz oraz miłość Poety z wierszem silniejszym od ludzkiego przemijania współtworzą świat przeczący wyobrażeniom tzw. zjadaczy chleba. Świat dosłownie wykreowany i w pełni dany jedynie samemu Przybosiowi.

Zdawałoby się, że miłosna historia była może nawet banalna:

Spotkali się w 1927 r. w Cieszynie, w oddziale matematyczno-przyrodniczym gimnazjum im. Osuchowskiego, dokąd autor „W głąb las” przybył jako nauczyciel języka polskiego, a Marzenę przeniosła matka (czeska literatka pochodzenia z Zaolzia) z zakopiańskiej szkoły, zaniepokojona wspinaczkowymi wyczynami córki. Przyboś obdarzył Marzenę głębokim uczuciem, a i ona przez pewien czas była mu wzajemną. Profesor Adam Przyboś nazwał ją kilkakrotnie „narzeczoną Julka”. [...]

W czerwcu 1929 r. ukończyła ona cieszyńskie gimnazjum, opuściła miasto, a w kilka miesięcy później tragicznie zginęła. Organizatorem pogrzebu w Zakopanem był Julian Przyboś, gdyż zrozpaczona matka (zwana tatrzańską Niobe) była zupełnie załamana. Współcześni temu wydarzeniu pamiętają wielkie skupienie poety, powściągliwość i szlachetność wobec matki Marzeny, z którą zdążył się wcześniej zaprzyjaźnić. [...] 
Nie stanął też poeta w miejscu, gdzie wydarzyła się katastrofa. Nie był on nigdy turystą wysokogórskim - nie pozwalał mu na to stan zdrowia i lęk przestrzeni, do którego sam się przyznawał - a podejście pod Zamarłą nie jest spacerem. Taternictwo poznał dobrze przez Marzenę, jej śmierć spotęgowała niechęć do gór i uczucie przytłoczenia ich ogromem. Walczył z tym pisarz przez całe życie i trzeba było wielu dziesiątków lat, aby tę obsesję przezwyciężyć. ${ }^{18}$

Mniejsza o psychologiczne dystynkcje, np. „obsesja” gór czy może jednak, choćby tylko estetyczna, fascynacja nimi? Tej drugiej dowodzą stosunkowo liczne wiersze poświęcone Alpom. Ważniejsze bowiem to, że nawet ćwierćwiecze później, kiedy Przyboś wspomnieniami powróci do ostatniej wspinaczki Marzeny, także wówczas konstrukcja obrazu poetyckiego przeważy nad faktograficzną materią. W tomiku Najmniej słów (1955) znajdziemy wiersz Tam, w urwisku. Przeczytamy:

A jeszcze tam, w urwisku, lina po tobie

drży,

gdy tu, za siódmą górą, ja tym oto, ledwo

pochyłym

wzgórkiem, lecz tak ostatnim, że pochował twoją

pamięć,

schodzę $[\ldots]^{19}$

Owa lina może wywoływać skojarzenia emocjonalne („po tobie drży” - ze strachu bądź z żalu? drga po zerwaniu się?), muzyczne (struny instrumentów) czy tylko dźwiękowe (niczym jęk wiatru w olinowaniu żaglowców), jednak lina pozostała po ostatniej drodze sióstr nie drżała niczym poetycka symbolika taternickiej śmierci. Obciążona spadającymi siostrami i wyrywana z karabinka nieprawidłowo wpiętego w hak, wspólnie z nimi spadła na piargi Pustej Dolinki. Co najwyżej mogła bezładnie przykryć ciała taterniczek. Jeszcze ćwierć wieku po osobistej tragedii Przyboś, wbrew swej wiedzy o taternickich realiach, konstruował znamienny obraz poetycki: poruszający, lecz w dosłownym rozumieniu fikcyjny. Zarazem poetycki

\footnotetext{
18 K. Heska-Kwaśniewicz Wokół genezy i tekstu "Z Tatr"Juliana Przybosia.

19 J. Przyboś Tam, w urwisku, w: J. Przyboś Utwory poetyckie. Zbiór, s. 218.
} 
- poniekąd także wbrew temu, że ówczesne liny były konopne, a więc po prostu szorstkie.

Jak wyjaśnić to, że w świecie przedstawionym słowem Przybosia siostry Skotnicówny zamieniają się miejscami (tzn. prowadząca Lida niejako stała się asekurującą Marzeną - i odwrotnie), a opadła na piargowe dno urwiska lina ćwierć wieku później wciąż jeszcze drży w ścianie Zamarłej Turni? O taternickiej niekompetencji mówić trudno - powtórzę: Przyboś „Taternictwo poznał dobrze przez Marzenę"20. Wyjaśnienie znajdziemy w dziele wciąż podstawowym dla teorii poezji.

Arystoteles pisał:

W sztuce poetyckiej istnieje możliwość popełnienia dwojakiego rodzaju błędu. Jeden rodzaj dotyczy istoty samej sztuki, drugi - spraw dla sztuki przypadkowych. Jeśli więc poeta podjął się naśladowania [przez Stagirytę rozumianego jako sztuka kreowania sugestywnych przedstawień słownych - K.O.], lecz nie przeprowadził go należycie ze względu na swą nieudolność, popełnia błąd istotny dla sztuki poetyckiej. Jeśli natomiast przedstawi coś niewłaściwie, jak np. konia, który podnosi jednocześnie obie prawe nogi, lub coś, co byłoby błędem z punktu widzenia medycyny czy jakiejś innej sztuki, jego błąd nie dotyczy istoty sztuki poetyckiej. ${ }^{21}$

To wszakże jeszcze przez Arystotelesa sformułowane rozróżnienie dwóch rodzajów błędów poetyckich (przeciwko istocie sztuki oraz jedynie - powiedzmy - technicznych) pozwala obronić Przybosiową konstrukcję słownych przedstawień taternickiej tragedii przed zarzutami dla poezji nieistotnymi. Nawet zamiana sióstr (Marzena versus Lida) czy konopna „lina po tobie" to jedynie ewentualne błędy w "sprawach dla sztuki przypadkowych". Więcej, można nawet o nich twierdzić, że były konieczne. Niejako siłą poetyckiej rzeczy (teoria ekwiwalentyzowania uczuć) podczas ostatniego wyciągu drugoplanowa i statyczna, gdyż asekurująca Lidę Marzena, stała się postacią pierwszoplanową i dynamiczną. Takiego jej przewyższenia nad prowadzącą wyciąg Lidą wymagała poetycka perswazja - zmaterializowana słowami wiersza i spotęgowana dedykacją, która tatrzańskiej tragedii dała wymiar dosłownie osobisty: emocje Lidy poprzez medium wiersza Przybosia stawały się emocjami Marzeny oraz czytelniczego audytorium.

K. Heska-Kwaśniewicz Wokółgenezy i tekstu „ZTatr”Juliana Przybosia. 
W polemice z krytyką czy też pseudokrytyką homerycką Arystoteles jednoznacznie opowiedział się za sztuką poetycką jako tym, co pozwala czy nawet nakazuje wznosić się ponad błędy techniczne: „Byłyby przecież nie do zniesienia niedorzeczności, jakie występują w Odysei w scenie przybycia Odysa na Itakę, gdyby posłużył się nimi jakiś mierny poeta. Tymczasem Homer czarem swej sztuki poetyckiej sprawił, że stały się one niewidoczne"22. Podobnie można by powiedzieć o wierszu Z Tatr i jego pogłosie w wierszu Tam, w urwisku: ich autor swą sztuką poetycką sprawił, że sprzeczna z tragiczną faktografią zamiana miejsc sióstr i taternicko niedorzecznie drżąca w ścianie lina stawały się poetycką może nawet koniecznością. Przyboś, konstruktor świata przedstawionego słowami tych dwóch wierszy (Z Tatr; Tam, w urwi$s k u$ ), trudno powiedzieć czy świadomie, pozostał wierny temu twierdzeniu Arystotelesa: „Poeta powinien przedstawiać raczej zdarzenia niemożliwe, lecz prawdopodobne niż możliwe, ale nieprawdopodobne"23. Podobnie jak Witkacy bywał Arystotelesem "podszyty"24, tak również Przyboś byłby należał do perypatetyckiej akademii? Twierdząca odpowiedź pośrednio zawiera się w tych słowach Witkacego: „W filozofii i estetyce stworzenie czegoś kompletnie nowego jest prawie niemożliwym. Od wieków jedno i to samo zagadnienie jest formułowane w coraz to inny sposób" ${ }^{25}$. Wśród takich zagadnień, przez wieki żywotnych, pozostaje problematyka statusów Natury i Kultury oraz ich relacji.

Jaką wypowiedzią będzie wiersz Z Tatr czytany w kontekście postkonstruktywizmu i konstruktywizmu kulturowego? Wstępnym i koniecznym warunkiem formułowania odpowiedzi powinno być wyjaśnienie, które przyjmuję za Tomaszem Szymonem Markiewką (aby pozostać w „koleinach” wyznaczonych jego tekstem).

Chcę jednak podkreślić, że obydwa pojęcia wchodzące w skład tego dualizmu traktuję tutaj bardzo szeroko. Przez naturę rozumiem to, co w tradycyjnym podejściu (esencjalistyczno-fundacjonalistycznym) uważa się za niezależne od człowieka, obiektywne, niezmienne i odkrywane przez

22

Tamże, s. 8 o.

Tamże, s. 79.

K. Obremski Witkacy Arystotelesem „podszyty”. "Mimesis” i Czysta Forma, "Teksty Drugie” 1999 nr 6, s. 139-147.

S.I. Witkiewicz O znaczeniu filozofii dla krytyki i inne artykuły polemiczne, oprac. J. Leszczyński, posłowie B. Dziemidok, PWN, Warszawa 1976, s. 35. 
niego. Pojęcie kultura oznacza zaś to, co jest przez człowieka stwarzane i co jest od niego zależne (a więc także wszystkie czynniki społeczne i językowe). Stąd też dualizm kultury i natury, tak jak go rozumiem w tym tekście, zawiera w sobie inne podobne dualizmy (np. rzeczywistość język, fakty - interpretacje, przedmiot - podmiot itp. $)^{26}$

Przyjąwszy takie rozumienie, należy stwierdzić: w świecie przedstawionym wierszem Z Tatr Natura i Kultura zarazem są samoistne oraz przenikają się. Tatrzańskie szczyty pozostają „niezależne od człowieka, obiektywne, niezmienne i odkrywane przez niego". Taternictwo to obcy w świecie tatrzańskiej przyrody czynnik człowieczy. Odwaga silniejsza niż naturalny strach przed upadkiem w przepaść, technika wspinania, sprzęt - to wszystko nie przekreśla zależności wspinaczy od siły przyciągania ziemskiego oraz od praw przyrody, w tym od nieoczekiwanych załamań pogody. Zarazem, tym bardziej współcześnie, Tatry Wysokie mogą jawić się jako Natura po części poddana Kulturze: ludzie pobudowali wysokogórskie schroniska, na Giewoncie stoi krzyż, w szczególnie trudnych dla turystów miejscach (np. jak na Orlej Perci) szlaki piesze są zabezpieczone metalowymi klamrami, drabinkami i łańcuchami, na ratunek może przylecieć helikopter. Zwierzyna raczej ustępuje człowiekowi - może wyłączywszy niedźwiedzie. Mimo dążeń do ograniczania ludzkiej obecności tzw. stonce turystycznej trudno poniechać szczególnie widoku Morskiego Oka i tamtejszych szczytów sięgających nieba. Taternicy też mają co nieco na sumieniu, nawet jeśli już nie kruszą skały hakami wbijanymi w szczeliny i wybijanymi z nich, lecz sięgają po kości wspinaczkowe (wielokształtne kostki osadzane w rysach) czy friendy (kości mechaniczne, tzn. przy wkładaniu w szczelinę rozszerzające się, przy wyjmowaniu zmniejszające się).

Jak usytuować wiersz Z Tatr w kontekście Problemu dualistycznego podziatu na naturęi kulturę - materii spornej postkonstruktywistów i konstruktywistów kulturowych? Jedni i drudzy sami powinni odpowiadać, przy czym ich dialog (podobnie jak to ma się z ekumenicznym) może przypominać sekwencję dwóch monologów. Postkonstruktywiści mogliby powiedzieć: wyzwoliwszy się spod zniewalającej mocy Kultury, powróćmy do badania Natury, tj. tatrzańskiej rzeczy i jej materialności. W tym nawet fizjologii:

26 T.S. Markiewka Problem dualistycznego podziału na naturę $i$ kulturę, "Przegląd Kulturoznawczy” $2013 \mathrm{nr} 1$, s. 102. 
- dygotanie łydek wspinaczy, zmęczonych długim staniem w ścianie na czubkach palców, (jakże niepoetycko?) bywa nazywane „telegrafem”;

- w książce Wawrzyńca Żuławskiego znajdziemy (jakby wbrew poetyckiej aurze taternickiej śmierci) zdjęcie opatrzone podpisem: „Transport ofiary wypadku w Tatrach"; nie ma wątpliwości: ofiary śmiertelnej - ciało jest znoszone przez dwóch ratowników w siatce zawieszonej na długim drągu; jednak na dalszym planie zdjęcia dojrzymy, wtopionych w tło skalnego urwiska, jeszcze dwóch ratowników - jeden spogląda w przepaść, drugi zaś, odwrócony od obiektywu aparatu, po prostu siusia;

- zdawałoby się jednak elitarne środowisko taterników miało problemy z zachowaniem kultury sanitarnej, toteż niegdyś, jeszcze w latach PRL, kierownik ich obozu w Morskim Oku obok wychodka nakazał umieścić napis: „Wysrałeś się - umyj ręce”.

Co na to mogła by powiedzieć druga strona sporu o podział na Naturę i Kulturę? Konstruktywista kulturowy wypowiedziałby się wpierw ogólnie:

Konstruktywista kulturowy wyjaśnia wtedy, że oczywiście nie chodzi mu o to, iż istnieje tylko język, kultura czy społeczeństwo. Uznaje on, że istnieją rzeczy, które nie są tworzone za pomocą języka czy kultury, ale $i$ to jest jego podstawowa teza - kiedy poznajemy te rzeczy, kiedy chcemy przypisać im jakieś właściwości, kiedy pragniemy wpleść je w nasz świat, zawsze robimy to za pomocą narzędzi kulturowych. Istnieje więc jakaś rzeczywistość pozakulturowa, ale pełni ona tylko rolę bodźców. To, jak te bodźce zinterpretujemy i to, jaką funkcję będą pełniły w naszym życiu, zależy już od kulturowych uwarunkowań. Sama rzeczywistość pozajęzykowa nie determinuje bowiem, jakiego rodzaju języka mamy użyć do jej opisania ${ }^{27}$.

Następnie m ó g ł by problem przedstawić jednostkowo: Tatry istnieją niczym „rzecz sama w sobie” - ich przyrodniczy status nie jest zależny od języka czy kultury (chociaż ludzie stanowią zagrożenie dla naturalnych walorów wysokogórskiej przyrody). Każdy ludzki kontakt z nimi (vide Przybosiowi „barbarzyńcy wiszący na linie” czy potoczna „stonka turystyczna”) dokonuje się poprzez medium narzędzi zwanych kulturowymi. Jako wieloraki kompleks bodźców Tatry jednym nakazują wspinać się na ich szczyty, innym pisać wiersze, niekiedy także o ofiarach tatrzańskich tragedii. Skotnicówny odważyły się 
podjąć (wówczas ekstremalne) taternickie wyzwanie, analogicznie Przyboś zmierzył się z taką poetycką powinnością, jaką było dla niego ekwiwalentyzowanie uczuć.

Jacek Woźniakowski, autor Gór niewzruszonych, jako motto książki wybrał te słowa: „Choć w naturze wiele jest rzeczy indywidualnych i nieporównywalnych, rozum obmyśla dla nich paralele, związki i pokrewieństwa, które nie istnieją" (Francis Bacon). Podobnie byłoby z siostrami leżącymi na piargach Pustej Dolinki? Niegdyś, w mitycznym „tam i wówczas”, Ikar wzleciał za wysoko - w poetyckim "tu i teraz" siostry Skotnicówny wspięły się tam, gdzie nie było im dane dojść końca taternickiej drogi. Ikar poleciał za wysoko, więc zawiodły go woskowe skrzydła - jedna z sióstr nieprawidłowo wpięła karabinek i ten nie wytrzymał siły upadku spadającej Lidy. Ikar oraz taterniczki to ofiary zarówno własnych błędów, jak też (bezdusznej?) Natury. Niebieskie morze i szare piargi stały się kresami ludzkiego życia. Obydwa upadki współtworzą analogię, która sięga dalej czy może raczej głębiej niż jedynie młodzieńcze błędy, materia ściśle techniczna (stopiony wosk skrzydeł - rozgięty karabinek) czy miejsca śmiertelnych upadków (morskie wody - tatrzańska dolina). To w micie Ikara tragedia Marzeny i Lidy znajduje swe najogólniejsze kulturowe zwieńczenie.

Siostry Skotnicówny, jako ofiary wspinaczki, oraz Przybosia, jako autora wiersza Z Tatr, można postrzegać w najszerszej perspektywie: niczym „zderzenie” Natury i Kultury. Papież awangardy pisał: „Człowiek dzisiejszy nie korzy się już przed naturą, lecz odnosi się do niej jak do dojnej krowy"28. Wtórował mu Poeta: „Natura nie dlatego jest «dojną krową», że daje bez troski mleko, ale dlatego, że jesteśmy dość silni, aby tę krowę wydoić” ${ }^{29}$. Taż „dojna krowa" z czasem okazała się dosłownie śmiertelnym zagrożeniem - w liście do stryjenki Przyboś napisał: „Spotkał mnie straszny cios: oto jadę na pogrzeb najdroższej mi istoty. Czy czytaliście o śmierci dwu turystek na Zamarłej Turni? Umarły dwa wyniosłe orle serca”30. Która strona z tego „zderzenia” Natury i Kultury wyszła zwycięsko? Niepodobna definitywnie rozstrzygnąć. Natura? - Tatry wszak dalej pozostały „górami niewzruszonymi”. Kultura? współcześnie wówczas ekstremalna droga wspinaczkowa dziś jest już tylko szkolną...

Cyt. za: E. Balcerzan Wstęp, s. XXVI.

Cyt. za: tamże. 
Natura oraz Kultura mówią „językami” dla siebie obcymi. Pierwsza nie czyta ani nawet nie słucha wierszy - druga już taśmowo, w skali poniekąd przemysłowej, produkuje tatrzańskie, alpejskie, himalajskie czy andyjskie ofiary „gór niewzruszonych". Wysokogórska kultura może nawet bywa swoistą antykulturą, np. niekiedy schronieni w namiocie himalaiści, aby nie wychodzić z namiotu, losują czyj kask stanie się wspólnym nocnikiem - by trzeba było jedynie wysunąć na zewnątrz rękę i wylać z niego mocz.

Historycznie problem wygląda interesująco: śledząc dzieje stosunku do ekskrementów, można bowiem zobaczyć przemiany wyobrażeń dotyczące relacji człowieka, cielesności, fizjologii, zdrowia, ale też i kwestii najbardziej podstawowych: statusu człowieka, jego miejsca we wszechświecie, relacji do natury itd. [...] Cielesność niesie zagrożenie dla porządku - to, co dzieje się w organizmie (przemiana materii, wydalanie, choroby, destrukcja), może mieć zbyt anarchiczny charakter - więc szczególnie ona wymaga narzucenia ładu, przynajmniej dyskursywnego. ${ }^{31}$

Dyskursywność taternickiego ładu wyklucza to, co niestosowne - zarazem Przybosiowe ekwiwalentyzowanie uczuć już samo przez się tzw. zwierzęcy strach przed śmiercią przetwarzało na materię poetyckiej sztuki słowa. Tabu i poezja współtworzyły relację sprzężenia zwrotnego. Jednak w górach najwyższych oraz na obydwu biegunach ziemskiej kuli (przynajmniej tam, gdzie dotąd ocieplenie klimatu nie rozmroziło śniegów czy lodów) fizjologiczne znaki ludzkiej obecności, tj. ekskrementy, pozostają tak wieczne, jak owe góry. Te ludzkie należą do Kultury; te zwierzęce - do Natury.

31 P. Kowalski O tym co nieuniknione: ekskrementy i defekacja, w: Ciało cielesne, red. K. Konarska, Wydawnictwo UWr, Wrocław 2011, s. 20-36. 


\section{Abstract}

\section{Krzysztof Obremski}

NICOLAUS COPERNICUS UNIVERSITY (TORUŃ)

The Lyrical Situation and the Constructivist Division of Nature and Culture: Julian Przyboś, "ZTatr" [From the Tatra Mountains]

This article presents an interpretation of Julian Przybośs poem "Z Tatr" [From the Tatra Mountains]. Obremski focuses on two problems. First, in Przybośs poem the Skotnicówna sisters seem to have exchanged positions - the aerial lift operator Lida takes Marzena's supportive position and vice versa; through the medium of the poem Lida's feelings become Marzena's, Julian Przyboś's as well as the readers'. Second, Nature and Culture seem to speak their own mutually incomprehensible languages. The discursivity of the Tatra-mountain order excludes that which is inappropriate; at the same time, Przyboś's tendency to present emotions as equivalent has transformed the so-called animal fear of death into the matter of the poetic art of language.

\section{Keywords}

Julian Przyboś, Marzena Skotnicówna, Lida Skotnicówna, Zamarła Turnia Mountain 